\title{
Universiteit
}

Leiden

The Netherlands

\section{Determination of the 3D genome organization of bacteria using Hi-C}

Crémazy, F.G.E.; Rashid, F.Z.M.; Haycocks, J.R.; Lamberte, L.E.; Grainger, D.C.; Dame, R.T.

\section{Citation}

Crémazy, F. G. E., Rashid, F. Z. M., Haycocks, J. R., Lamberte, L. E., Grainger, D. C., \& Dame, R. T. (2018). Determination of the 3D genome organization of bacteria using Hi-C. In Methods in Molecular Biology (Vol. 1837, pp. 3-18). New York, U.S.A.: Humana Press.

doi:10.1007/978-1-4939-8675-0_1

Version: $\quad$ Publisher's Version

License: $\quad$ Licensed under Article 25fa Copyright Act/Law (Amendment Taverne)

Downloaded from: https://hdl.handle.net/1887/72495

Note: To cite this publication please use the final published version (if applicable). 


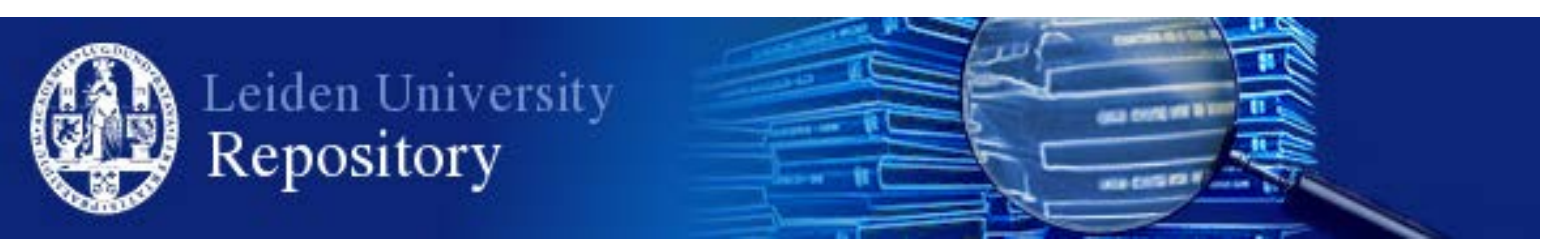

\section{https://openaccess.leidenuniv.nl}

\section{License: Article 25fa pilot End User Agreement}

This publication is distributed under the terms of Article 25fa of the Dutch Copyright Act (Auteurswet) with explicit consent by the author. Dutch law entitles the maker of a short scientific work funded either wholly or partially by Dutch public funds to make that work publicly available for no consideration following a reasonable period of time after the work was first published, provided that clear reference is made to the source of the first publication of the work.

This publication is distributed under The Association of Universities in the Netherlands (VSNU) 'Article $25 \mathrm{fa}$ implementation' pilot project. In this pilot research outputs of researchers employed by Dutch Universities that comply with the legal requirements of Article $25 \mathrm{fa}$ of the Dutch Copyright Act are distributed online and free of cost or other barriers in institutional repositories. Research outputs are distributed six months after their first online publication in the original published version and with proper attribution to the source of the original publication.

You are permitted to download and use the publication for personal purposes. All rights remain with the author(s) and/or copyrights owner(s) of this work. Any use of the publication other than authorised under this licence or copyright law is prohibited.

If you believe that digital publication of certain material infringes any of your rights or (privacy) interests, please let the Library know, stating your reasons. In case of a legitimate complaint, the Library will make the material inaccessible and/or remove it from the website. Please contact the Library through email: OpenAccess@library.leidenuniv.nl

\section{Article details}

Crémazy F.G.E., Rashid F.Z.M., Haycocks J.R., Lamberte L.E., Grainger D.C. \& Dame R.T. (2018), Determination of the 3D genome organization of bacteria using Hi-C. In: Dame R.T. (Ed.) Bacterial Chromatin: Methods and Protocols. Methods in Molecular Biology no. 1837. 3-18.Doi: 10.1007/978-1-4939-8675-0_1 


\title{
Determination of the 3D Genome Organization of Bacteria Using Hi-C
}

\author{
Frédéric G. Crémazy, Fatema-Zahra M. Rashid, James R. Haycocks, \\ Lisa E. Lamberte, David C. Grainger, and Remus T. Dame
}

\begin{abstract}
The spatial organization of genomes is based on their hierarchical compartmentalization in topological domains. There is growing evidence that bacterial genomes are organized into insulated domains similar to the Topologically Associating Domains (TADs) detected in eukaryotic cells. Chromosome conformation capture (3C) technologies are used to analyze in vivo DNA proximity based on ligation of distal DNA segments crossed-linked by bridging proteins. By combining 3C and high-throughput sequencing, the $\mathrm{Hi}-\mathrm{C}$ method reveals genome-wide interactions within topological domains and global genome structure as a whole. This chapter provides detailed guidelines for the preparation of $\mathrm{Hi}$-C sequencing libraries for bacteria.
\end{abstract}

Key words Hi-C, Chromosome, Bacterial chromatin

1 Introduction

Over the last decade, Chromosome Conformation Capture (3C)based methods have been used to resolve the $3 \mathrm{D}$ conformation of genomes in eukaryotes [1]. The techniques have revealed how genomes are organized and how this organization can influence gene expression through long-range physical interactions between regulatory elements $[2,3]$. Hi-C is possibly the most powerful of the $3 \mathrm{C}$-based methods as it allows the interrogation of all possible interactions across the genome in an unbiased manner at a resolution of up to $5 \mathrm{~kb}[4]$.

Only recently, Hi-C has been used to probe chromosome conformation in prokaryotes [5-7]. The first genome-wide interaction frequency maps obtained from Bacillus subtilis and Caulobacter crescentus demonstrated that, as in eukaryotes, bacterial

Frédéric G. Crémazy and Fatema-Zahra M. Rashid contributed equally to this work 
genomes are organized into large-scale insulated chromosomal structures called Chromosome Interactions Domains (CID). The formation and maintenance of these domains is correlated with DNA transactions such as transcription [6]. Hi-C has also revealed how the 3D structure of the ori macrodomain influences DNA replication initiation and chromosome segregation [7]. These results underline the relevance of using $\mathrm{Hi}-\mathrm{C}$ to correlate $3 \mathrm{D}$ structure of genomes with genome function.

Like other $3 \mathrm{C}$-based methods, $\mathrm{Hi}$ - $\mathrm{C}$ relies on the proximity ligation of DNA fragments connected together by architectural proteins to probe the $3 \mathrm{D}$ organization of the chromosome (see Fig. 1). First, a snapshot of the chromosome is obtained by treating

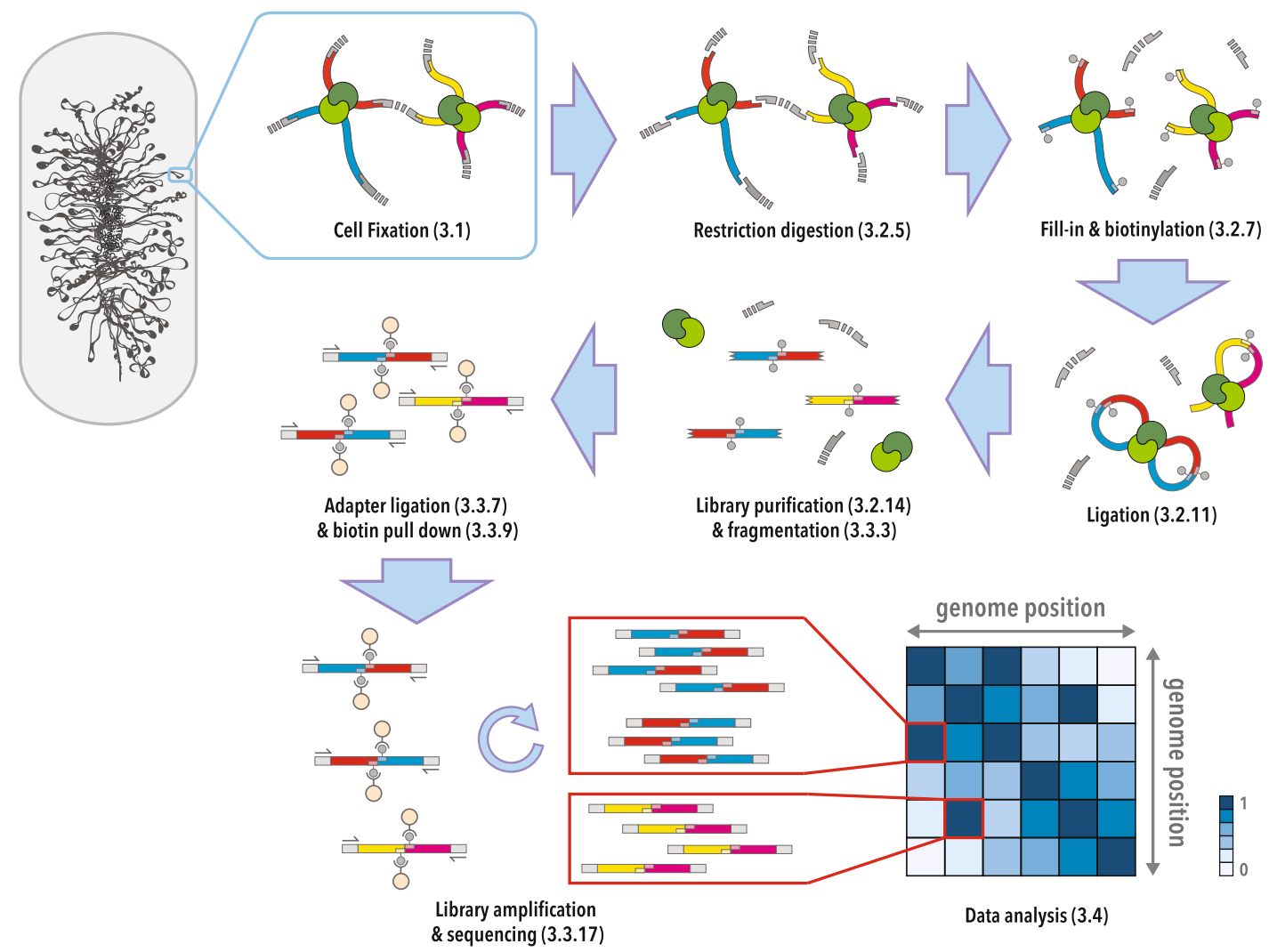

Fig. 1 Schematic overview of the Hi-C method. Bacteria are cultured and fixed using formaldehyde to crosslink proteins to DNA (proteins are shown in green, DNA fragments of interest in various colors and other DNA fragments in gray dotted lines). After cell lysis, bacterial chromatin is digested with a restriction enzyme and the cohesive extremities are filled using T4 DNA polymerase in buffer containing a biotinylated nucleotide (light colors and gray circles). The digested DNA fragments are then diluted tenfold and ligated overnight. After cross-link reversal and protein digestion, the purified DNA is fragmented enzymatically. For next-generation sequencing, barcoded adapters are ligated to the DNA and the library is enriched for biotinylated junctions using streptavidin beads (light brown circles). The library is further amplified by PCR and analyzed by pairedend sequencing. After mapping and filtering of all the junctions, genome-wide interactions are displayed as a colored matrix 
bacterial cells with a fixative, usually formaldehyde. After lysis of the cells, the chromatin is digested using a restriction enzyme, either a 6- or 4-base pair cutter, fragmenting the genome into a heterogeneous population of DNA-protein complexes. Interactions between distal DNA segments are retained after fragmentation. Hence, overhanging DNA ends generated by restriction can be filled using biotin-labeled nucleotides and blunt end ligated. Ligation is carried out in dilute conditions to favor ligation of DNA fragments in the same cross-linked chromatin complex. Hence, the chance of ligation between unlinked DNA fragments is minimized. After reverse crosslinking and DNA purification, biotin labels from unligated restriction fragment ends are removed using the exonuclease activity of T4 DNA polymerase. The library produced is then fragmented and the biotin-labelled junctions are enriched using streptavidin-coated magnetic beads. The ligation-junctions are identified by paired-end sequencing. After filtering and mapping of the reads to a reference genome, a genome-wide proximity map is generated in the form of a matrix of pairwise interaction frequencies across the genome.

In this chapter, we present a detailed protocol for the preparation of Hi-C libraries from the bacterium Escherichia coli and subsequent high-throughput sequencing. Data analysis and methods for generating $\mathrm{Hi}-\mathrm{C}$ interaction maps are explained in more detail in Chapter 2 of this book.

\section{Materials}

\subsection{Cell Fixation}

1. $1 \times$ PBS solution: $137 \mathrm{mM} \mathrm{NaCl}, 2.7 \mathrm{mM} \mathrm{KCl}, 4.3 \mathrm{mM}$ $\mathrm{Na}_{2} \mathrm{HPO}_{4}, 1.47 \mathrm{mM} \mathrm{KH} \mathrm{PO}_{4}, \mathrm{pH}$ 7.4. Place the solution on ice.

2. $37 \% \mathrm{w} / \mathrm{v}$ formaldehyde solution.

3. $3 \% \mathrm{v} / \mathrm{v}$ formaldehyde solution: Add $1.6 \mathrm{~mL}$ of $37 \% \mathrm{w} / \mathrm{v}$ formaldehyde solution to $18.4 \mathrm{~mL}$ of cold $1 \times$ PBS solution (see Note 1). Freshly prepare the $3 \%$ formaldehyde and place it on ice. Keep the solution away from direct sunlight.

4. 2.5 M Glycine solution filter-sterilized using a sterile, non-pyrogenic $0.2 \mu \mathrm{m}$ filter.

5. $1 \times$ TE Buffer: $10 \mathrm{mM}$ Tris-HCl, $1 \mathrm{mM}$ EDTA $\cdot \mathrm{Na}_{2}, \mathrm{pH}$ 8.0.

6. Dry ice.

7. Refrigerated benchtop centrifuge (e.g., Eppendorf centrifuge $5810 \mathrm{R}$ or $5430 \mathrm{R})$.

8. Roller bench.

9. $-80{ }^{\circ} \mathrm{C}$ freezer.

10. $50 \mathrm{~mL}$ Falcon tubes. 
11. Serological pipettes.

12. Pipette pump.

13. Elongated Pasteur pipette (made of soda lime silica glass): Heat a $1 \mathrm{~cm}$ space of the Pasteur pipette above the tip and stretch the heated region to reduce the diameter of the pipette bore. Use a pair of tweezers to carefully break the pipette at the elongated region to produce a Pasteur pipette with a narrow opening.

14. $1000 \mu \mathrm{L}$ micropipette.

15. Sterile $1.5 \mathrm{~mL}$ microfuge tubes.

2.2 Hi-C Library Preparation
1. $\mathrm{l} \times$ TE Buffer: $10 \mathrm{mM}$ Tris-HCl, $1 \mathrm{mM}$ EDTA $\cdot \mathrm{Na}_{2}, \mathrm{pH}$ 8.0.

2. 40,000 U/ $\mu \mathrm{L}$ Ready-Lyse Lysozyme (Epicentre).

3. $1.0 \mathrm{M} \mathrm{NaCl}$.

4. Nuclease-free water.

5. $10 \% \mathrm{w} / \mathrm{v}$ sodium dodecyl sulfate (SDS) solution: Dissolve $1.0 \mathrm{~g}$ of SDS (ACS reagent, $\geq 99.0 \%$ ) in $10 \mathrm{~mL}$ of nuclease-free water.

6. $10 \% \mathrm{v} / \mathrm{v}$ Triton X-100 solution: Dilute $1.0 \mathrm{~mL}$ of Triton X-100 (molecular biology grade) with $9.0 \mathrm{~mL}$ of nuclease-free water. Store the solution at room temperature $\left(20^{\circ} \mathrm{C}-25^{\circ} \mathrm{C}\right)$ in the dark.

7. $10 \times$ restriction enzyme buffer (as supplied with the restriction enzyme).

8. Selected restriction enzyme (see Note 2).

9. $100 \mathrm{mM}$ deoxynucleotides (ultrapure dNTPs as separate solutions). Repeated freeze-thaw cycles may result in the degradation of dNTPs. To minimize degradation of the $100 \mathrm{mM}$ stock, dilute $20.0 \mu \mathrm{L}$ of $100 \mathrm{mM} \mathrm{dNTP}$ with $180.0 \mu \mathrm{L}$ of nucleasefree water. Store the $10 \mathrm{mM}$ dNTP solution at $-20{ }^{\circ} \mathrm{C}$ as $50.0 \mu \mathrm{L}$ aliquots.

10. Separate solutions of $1 \mathrm{mM}$ dNTP: Dilute one $10 \mathrm{mM}$ dNTP aliquot tenfold with nuclease-free water. Store the dNTP solution at $-20^{\circ} \mathrm{C}$ and thaw on ice when necessary.

11. 0.4 mM biotin-14-dATP (see Note 3).

12. $5 \mathrm{U} / \mu \mathrm{L}$ DNA Polymerase I, Large (Klenow) fragment.

13. $20 \mathrm{mg} / \mathrm{mL}$ bovine serum albumin (BSA).

14. $10 \times$ T4 DNA Ligase buffer: $0.5 \mathrm{M}$ Tris- $\mathrm{HCl}, 0.1 \mathrm{M} \mathrm{MgCl}_{2}$, 10 mM ATP, 0.1 M DTT, pH 7.5.

15. $2000 \mathrm{U} / \mu \mathrm{L}$ T4 DNA Ligase.

16. 0.5 M EDTA, pH 8.0.

17. $10 \mathrm{mg} / \mathrm{mL}$ RNase A solution.

18. $20 \mathrm{mg} / \mathrm{mL}$ Proteinase K solution. 
19. 5.0 M NaCl solution.

20. 25:24:1 Phenol:chloroform:isoamyl alcohol solution.

21. Chloroform.

22. 1.0 M sodium acetate ( $\mathrm{NaOAc}), \mathrm{pH} 8.0$.

23. $5.0 \mathrm{mg} / \mathrm{mL}$ glycogen.

24. Cold $100 \%$ and $70 \%$ ethanol solutions.

25. $10 \mathrm{mM}$ Tris, $\mathrm{pH}$ 8.0.

26. dsDNA quantification kit (e.g., Qubit ${ }^{\circledR}$ dsDNA HS Assay Kit from ThermoFisher Scientific).

27. $10 \times$ T4 DNA Polymerase buffer: $0.5 \mathrm{M} \mathrm{NaCl}, 0.1 \mathrm{M}$ Tris- $\mathrm{HCl}, 0.1 \mathrm{M} \mathrm{MgCl}_{2}, 1 \mathrm{mg} / \mathrm{mL}$ BSA, pH 7.9 (available as NEBuffer 2.1).

28. $3 \mathrm{U} / \mu \mathrm{L}$ T4 DNA Polymerase.

29. Thermomixer (e.g., Eppendorf Thermomixer ${ }^{\circledR}$ C).

30. Benchtop centrifuge (e.g., Eppendorf MiniSpin ${ }^{\circledR}$ plus).

31. Vacuum concentrator.

32. Vortex mixer.

33. $-20{ }^{\circ} \mathrm{C}$ freezer.

34. $2.5 \mu \mathrm{L}, 20 \mu \mathrm{L}, 200 \mu \mathrm{L}$, and $1000 \mu \mathrm{L}$ micropipettes.

35. Sterile $1.5 \mathrm{~mL}$ microfuge tubes.

36. Agarose gel electrophoresis setup.

\subsection{NGS Library} Preparation
1. Solid Phase Reverse Immobilization (SPRI) beads (e.g., Agencourt AMPure XP from Beckman). Store the beads as $1.0 \mathrm{~mL}$ aliquots at $4{ }^{\circ} \mathrm{C}$. Ensure that the beads are equilibrated to room temperature and vortexed before use.

2. Elution buffer: $10 \mathrm{mM}$ Tris, $\mathrm{pH}$ 8.0.

3. Elution buffer $+0.1 \%$ Tween 20 .

4. Illumina ${ }^{\circledR}$ library preparation kit (e.g., KAPA HyperPlus kit from KAPA Biosystems).

5. Illumina ${ }^{\circledR}$-compatible paired-end sequencing adapters at a concentration of $15 \mu \mathrm{M}$ (e.g., KAPA Single-Indexed Adapter Sets $A$ and B from KAPA Biosystems). The sequencing adapters should be barcoded to allow multiplexing during NGS.

6. Magnetic rack (e.g., DynaMag ${ }^{\text {TM}}$-PCR Magnet from ThermoFisher Scientific).

7. Streptavidin-coupled magnetic beads optimized for the enrichment of biotin-labeled nucleic acids (e.g., Dynabeads ${ }^{\circledR}$ MyOne ${ }^{\mathrm{TM}}$ Streptavidin $\mathrm{Tl}$ from ThermoFisher Scientific). Store the beads at $4{ }^{\circ} \mathrm{C}$ and vortex well before use. 
8. $2 \times$ Beads Wash Buffer $(2 \times$ BWB $): 10 \mathrm{mM}$ Tris $\mathrm{pH} 7.5,1 \mathrm{mM}$ EDTA, $2 \mathrm{mM} \mathrm{NaCl}, 0.1 \%$ Tween 20.

9. $1 \times$ Beads Wash Buffer $(1 \times B W B): 5 \mathrm{mM}$ Tris $\mathrm{pH} 7.5,0.5 \mathrm{mM}$ EDTA, $1 \mathrm{mM} \mathrm{NaCl}, 0.1 \%$ Tween 20.

10. dsDNA quantification kit (e.g., Qubit ${ }^{\circledR}$ dsDNA HS Assay Kit from ThermoFisher Scientific).

11. Tapestation (Agilent Technologies) or Bioanalyzer (Agilent Technologies).

12. Thermal cycler with a heated lid.

13. Vortex mixer.

14. PCR tubes.

\section{Methods}

This protocol is optimized for HiC in Escherichia coli. To process other bacteria using this protocol, optimize the cell lysis and solubilization steps (see steps $\mathbf{2}$ and $\mathbf{3}$ of Subheading 3.2) by adjusting the treatment duration and/or the concentrations of Ready-Lyse Lysozyme and SDS.

\subsection{Cell Fixation}

1. Transfer $6.0 \mathrm{~mL}$ of the Escherichia coli culture at the mid-exponential phase $\left(\mathrm{OD}_{600}\right.$ of 1.0$)$ into a prechilled $50 \mathrm{~mL}$ Falcon tube (see Note 4).

2. Collect the cells by centrifugation at $5000 \mathrm{rpm}(3400 \times g)$ for 5 min at $4{ }^{\circ} \mathrm{C}$. Decant the supernatant and resuspend the cell pellet in $18.0 \mathrm{~mL}$ of cold $1 \times$ PBS to wash the bacterial cells $($ see Note 1).

3. Centrifuge the cells at $5000 \mathrm{rpm}(3400 \times g)$ for $5 \mathrm{~min}$ at $4{ }^{\circ} \mathrm{C}$ and discard the supernatant.

4. Resuspend the cell pellet in $18.0 \mathrm{~mL}$ of $3 \%$ formaldehyde solution. Incubate the cell suspension at $4{ }^{\circ} \mathrm{C}$ for $\mathrm{l}$ h on a roller bench at $30 \mathrm{rpm}$.

5. Add $3.2 \mathrm{~mL}$ of $2.5 \mathrm{M}$ glycine to the fixation reaction (to a final concentration of $0.375 \mathrm{M}$ ) to quench the excess formaldehyde. Incubate the cells for $15 \mathrm{~min}$ at $4{ }^{\circ} \mathrm{C}$ on a roller bench at $30 \mathrm{rpm}$.

6. Collect the fixed cells by centrifugation at $5000 \mathrm{rpm}(3400 \times g)$ for $5 \mathrm{~min}$ at $4{ }^{\circ} \mathrm{C}$. Pour out the supernatant and carefully remove the rest with a micropipette. Resuspend the cell pellet in $5.0 \mathrm{~mL}$ of $1 \times$ TE.

7. Divide the suspension of fixed cells into five aliquots of $1.0 \mathrm{~mL}$ in sterile $1.5 \mathrm{~mL}$ microfuge tubes (see Note $\mathbf{5}$ ). 
8. Pellet the fixed cells by centrifugation at $10,000 \mathrm{rpm}(10,600 \times g)$ for $2 \mathrm{~min}$ at $4{ }^{\circ} \mathrm{C}$. Remove the supernatant with an elongated Pasteur pipette.

9. Flash freeze the cell pellets in dry ice and store the fixed cells at $-80{ }^{\circ} \mathrm{C}$ for up to 2 months.

\subsection{Hi-C Library Preparation}

1. Resuspend a pellet of fixed cells in $50.0 \mu \mathrm{L}$ of $1 \times \mathrm{TE}$ and place the cell suspension on ice.

2. Prepare a 1:10 dilution of 40,000 U/ $\mu \mathrm{L}$ Ready-Lyse Lysozyme (Epicentre) with $4.0 \mu \mathrm{L}$ of $1 \times \mathrm{TE}, 0.5 \mu \mathrm{L}$ of $1.0 \mathrm{M}$ $\mathrm{NaCl}$, and $0.5 \mu \mathrm{L}$ of $40,000 \mathrm{U} / \mu \mathrm{L}$ Ready-Lyse Lysozyme. Add $0.5 \mu \mathrm{L}$ of the diluted enzyme to the cell suspension. Incubate the tube for $15 \mathrm{~min}$ at $37^{\circ} \mathrm{C}$ in a Thermomixer at $1000 \mathrm{rpm}$ to lyse the cells.

3. Add $2.5 \mu \mathrm{L}$ of $10 \%$ SDS to the lysis reaction and mix by pipetting. Incubate the tube for $15 \mathrm{~min}$ at $37^{\circ} \mathrm{C}$ in a Thermomixer at $1000 \mathrm{rpm}$.

4. $5.0 \mu \mathrm{L}$ of the cell lysate diluted with $45.0 \mu \mathrm{L}$ of $\mathrm{l} \times \mathrm{TE}$ may be kept aside at $-20^{\circ} \mathrm{C}$ as "chromatin." This control serves as a test to determine whether the extracted chromatin undergoes degradation during cell lysis and solubilization (see Fig. 2) (see steps 2 and 3 of Subheading 3.2). Continue with processing this control at step 13 of Subheading 3.2 and adjust the volume of the cell lysate to $53.0 \mu \mathrm{L}$ with $5.0 \mu \mathrm{L}$ of $\mathrm{l} \times \mathrm{TE}$ to continue with Hi-C library preparation.

5. Transfer $53.0 \mu \mathrm{L}$ of the cell lysate into $186.0 \mu \mathrm{L}$ of the restriction digestion mix $(136.0 \mu \mathrm{L}$ of nuclease-free water, $25.0 \mu \mathrm{L}$ of $10 \%$ Triton $\mathrm{X}-100$, and $25.0 \mu \mathrm{L}$ of $10 \times$ restriction enzyme buffer). Incubate the sample at $37^{\circ} \mathrm{C}$ for $10 \mathrm{~min}$ in a Thermomixer at $1000 \mathrm{rpm}$ to sequester SDS in the cell lysate with Triton X-100 in the digestion mix.

6. Add $100 \mathrm{U}$ of Restriction enzyme to the digestion mix and, if necessary, make up the volume of the reaction to $250 \mu \mathrm{L}$ with nuclease-free water. Incubate the reaction at $37^{\circ} \mathrm{C}$ for $3 \mathrm{~h}$ with shaking at $450 \mathrm{rpm}$.

7. Fill in the restriction ends and tag them with biotin by adding the following to $250 \mu \mathrm{L}$ of the digestion reaction: $3.0 \mu \mathrm{L}$ of $1.0 \mathrm{mM}$ dTTP, $3.0 \mu \mathrm{L}$ of $1.0 \mathrm{mM}$ dGTP, $3.0 \mu \mathrm{L}$ of $1.0 \mathrm{mM}$ dCTP, $7.5 \mu \mathrm{L}$ of $0.4 \mathrm{mM}$ biotin-14-dATP, $1.5 \mu \mathrm{L}$ of $20 \mathrm{mg} /$ $\mathrm{mL}$ BSA, $26.0 \mu \mathrm{L}$ of nuclease-free water, and $6.0 \mu \mathrm{L}$ of $5 \mathrm{U} / \mu \mathrm{L}$ DNA Polymerase I, Large (Klenow) fragment (see Note 3 ). Mix well by gently inverting the tube and incubate the reaction for $45 \mathrm{~min}$ at $25^{\circ} \mathrm{C}$ in a Thermomixer at $450 \mathrm{rpm}$.

8. Inactivate the restriction enzyme and Klenow fragment by adding $15.8 \mu \mathrm{L}$ of $10 \%$ SDS to the fill-in reaction to a final 


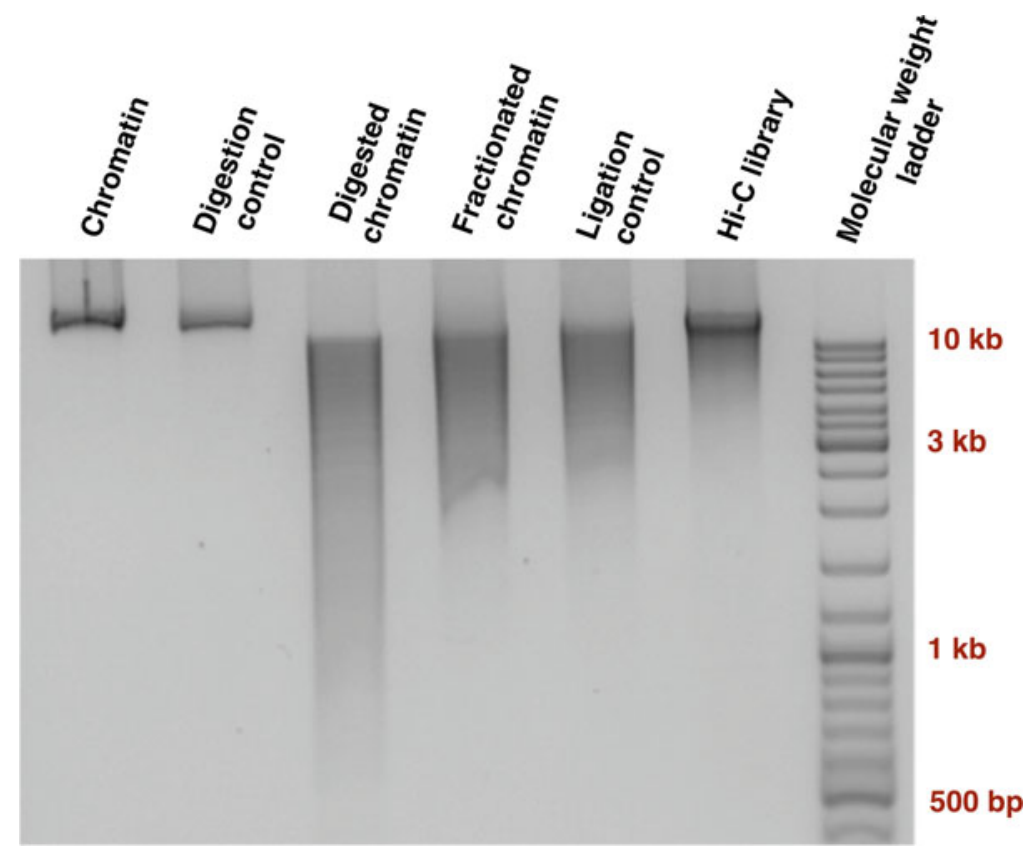

Fig. 2 Typical results obtained for different steps of the Hi-C library preparation. Chromatin: Chromatin extracted from fixed cells during lysis and solubilization runs as a high molecular weight band $>10 \mathrm{~kb}$. Digestion control: Chromatin incubated in the restriction digestion mix for three hours in the absence of a restriction enzyme should appear as a high molecular weight band similar to the chromatin lane. A smear in this control indicates that the chromatin undergoes degradation during restriction digestion. Digested chromatin: Chromatin digested with a 6-cutter should run as a smear with a bulk of the fragments having a size $>2 \mathrm{~kb}$. Fractionated chromatin: Fractionation pellets protein-cross linked DNA. "Free floating" DNA fragments that may contribute to random ligation and self-circularized products are eliminated. This step is associated with a loss of shorter fragments. Ligation control: Fractionated chromatin in the ligation mix in the absence of T4 DNA Ligase should run on the agarose gel with a profile comparable to fractionated chromatin. Degradation will be observed as a shift of the profile towards shorter DNA lengths. Hi-C library: A well-ligated $\mathrm{Hi}-\mathrm{C}$ library shows a shift of the DNA profile towards high molecular weights

concentration of $0.5 \%$. Mix well by gentle inversion and incubate the sample for $20 \mathrm{~min}$ at $25^{\circ} \mathrm{C}$ in a Thermomixer at $1000 \mathrm{rpm}$. Avoid inactivation at higher temperatures to minimize premature reverse cross-linking of the chromatin fragments.

9. Fractionate the chromatin by centrifuging the sample at $16,000 \mathrm{rpm}(25,200 \times \mathrm{g})$ for $\mathrm{l} \mathrm{h}$ at $4{ }^{\circ} \mathrm{C}$ and discard the supernatant. Resuspend the gel-like pellet in $200.0 \mu \mathrm{L}$ of Nuclease-Free Water. Use $2.0 \mu \mathrm{L}$ of the sample to determine the DNA concentration using the Qubit ${ }^{\circledR}$ dsDNA HS Assay Kit. 
10. Keep a $1.0 \mu \mathrm{g}$ aliquot aside as the $\mathrm{R}+$ control. This control is used to visualize the efficiency of restriction digestion (see Fig. 2). Make up the volume of the control to $50.0 \mu \mathrm{L}$ using $\mathrm{I} \times \mathrm{TE}$ and store it at $-20{ }^{\circ} \mathrm{C}$. Continue with processing the $\mathrm{R}+$ control at step $\mathbf{1 3}$ of this subsection.

11. Adjust the volumes of 1.0-2.0 $\mu \mathrm{g}$ aliquots of resuspended chromatin to $820 \mu \mathrm{L}$ with Nuclease-Free Water. Add $100.0 \mu \mathrm{L}$ of $10 \times$ T4 DNA Ligase Buffer, $75.0 \mu \mathrm{L}$ of $10 \%$ Triton X-100, and $5.0 \mu \mathrm{L}$ of $20 \mathrm{mg} / \mathrm{mL}$ BSA. Mix well by inversion and incubate the samples at $16{ }^{\circ} \mathrm{C}$ for $20 \mathrm{~min}$ in a Thermomixer at $1000 \mathrm{rpm}$ to sequester SDS.

12. Add $3.0 \mu \mathrm{L}$ of $2000 \mathrm{U} / \mu \mathrm{L}$ T4 DNA Ligase and incubate the reaction for $16 \mathrm{~h}$ at $16^{\circ} \mathrm{C}$. Terminate the ligation reaction by adding $20.5 \mu \mathrm{L}$ of $0.5 \mathrm{M}$ EDTA.

13. Add $16.6 \mu \mathrm{L}$ of $1: 10$ diluted $100 \mathrm{mg} / \mathrm{mL}$ RNase $A$ to the ligation reaction. Use $0.8 \mu \mathrm{L}$ for the Chromatin and $\mathrm{R}+$ control (see steps 4 and 10 of Subheading 3.2). Mix by pipetting and incubate the samples for $30 \mathrm{~min}$ at $37^{\circ} \mathrm{C}$ in a Thermomixer at $450 \mathrm{rpm}$.

14. Add $12.5 \mu \mathrm{L}$ of Qiagen Proteinase K solution and $120.8 \mu \mathrm{L}$ of $5.0 \mathrm{M} \mathrm{NaCl}$ to the ligation reaction. To the Chromatin and $\mathrm{R}+$ control (see steps 4 and 10 of Subheading 3.2), add $0.64 \mu \mathrm{L}$ of Qiagen Proteinase $\mathrm{K}$ solution and $6.2 \mu \mathrm{L}$ of $5.0 \mathrm{M} \mathrm{NaCl}$. Incubate the samples for $6 \mathrm{~h}$ at $65{ }^{\circ} \mathrm{C}$ in a Thermomixer at $450 \mathrm{rpm}$ to reverse formaldehyde-mediated cross-links and digest proteins.

15. Divide the ligation reaction over two tubes. Add an equal volume of 25:24:1 phenol:chloroform:isoamyl alcohol to ligation samples and controls and vortex the tubes for $10 \mathrm{~s}$. Centrifuge the samples for $10 \mathrm{~min}$ at 14,000 rpm $(19,300 \times g)$ on a benchtop centrifuge and transfer the top aqueous layer into a sterile $1.5 \mathrm{~mL}$ microfuge tube. Perform this step twice.

16. Place the ligation solutions in a Vacuum Concentrator for $1 \mathrm{~h}$ at $60{ }^{\circ} \mathrm{C}$ to reduce the sample volumes from 600 to $200 \mu \mathrm{L}$. Pool the solutions.

17. Add 0.1 volumes of $1.0 \mathrm{M}$ Sodium Acetate $\mathrm{pH} 8.0$ and 0.025 volumes of $5.0 \mathrm{mg} / \mathrm{mL}$ Glycogen to each sample and vortex well. Add 2.5 volumes of cold $100 \%$ ethanol. Mix the solutions well by inversion or vortexing and incubate the samples overnight at $-20{ }^{\circ} \mathrm{C}$.

18. Centrifuge the precipitation solutions for $20 \mathrm{~min}$ at $16,000 \mathrm{rpm}(25,200 \times g)$ at $4{ }^{\circ} \mathrm{C}$. Remove the supernatant with an elongated Pasteur pipette. A white pellet should be visible at the base of the microfuge tube. 
19. Add $500 \mu \mathrm{L}$ of cold $70 \%$ ethanol to the microfuge tube to wash the pellet. Centrifuge the tube at $16,000 \mathrm{rpm}(25,200 \times g)$ for $5 \mathrm{~min}$ at $4{ }^{\circ} \mathrm{C}$ and remove the supernatant with an elongated Pasteur pipette. Perform this step twice.

20. Dry the pellets in a $37{ }^{\circ} \mathrm{C}$ incubator for $15 \mathrm{~min}$ or on a benchtop for $1 \mathrm{~h}$. Dissolve each pellet in $17.0 \mu \mathrm{L}$ of $10 \mathrm{mM}$ Tris.

21. Use $2.0 \mu \mathrm{L}$ of the purified libraries and controls to determine DNA concentration using the Qubit ${ }^{\circledR}$ dsDNA HS Assay Kit.

22. Visualize between 100 and $500 \mathrm{ng}$ of each sample on a $1.5 \%$ Agarose gel. Ensure that between $500 \mathrm{ng}$ to $1.0 \mu \mathrm{g}$ of the purified, ligated Hi-C library is available for the next steps of the protocol (see Fig. 2).

23. To $15.0 \mu \mathrm{L}$ of the purified Hi-C library, add $23.75 \mu \mathrm{L}$ of nuclease-free water, $5.0 \mu \mathrm{L}$ of $10 \times$ NEBuffer $2.1,5.0 \mu \mathrm{L}$ of $1 \mathrm{mM}$ dGTP, $0.25 \mu \mathrm{L}$ of $20 \mathrm{mg} / \mathrm{mL}$ BSA, and $1.0 \mu \mathrm{L}$ of $3 \mathrm{U} / \mu$ L T4 DNA Polymerase. Incubate the reaction at $16{ }^{\circ} \mathrm{C}$ for $3 \mathrm{~h}$ in a Thermomixer at $450 \mathrm{rpm}$ ( see Note 6).

24. Add an equal volume of 25:24:1 phenol:chloroform:isoamyl alcohol to the sample and vigorously vortex the tube for $10 \mathrm{~s}$. Centrifuge the samples for $10 \mathrm{~min}$ at $14,000 \mathrm{rpm}(19,300 \times \mathfrak{g})$ on a benchtop centrifuge and transfer the top aqueous layer into a sterile $1.5 \mathrm{~mL}$ microfuge tube.

25. Add 0.1 volumes of 3.0 M Sodium Acetate $\mathrm{pH} 5.6$ and 0.025 volumes of $5.0 \mathrm{mg} / \mathrm{mL}$ Glycogen and vortex the sample well. Add 2.5 volumes of cold $100 \%$ ethanol and mix well by inversion. Incubate the sample at $-20{ }^{\circ} \mathrm{C}$ for at least $\mathrm{l} \mathrm{h}$.

26. Centrifuge the precipitation solution for $20 \mathrm{~min}$ at $16,000 \mathrm{rpm}(25,200 \times \mathrm{g})$ at $4{ }^{\circ} \mathrm{C}$ and remove the supernatant with an elongated Pasteur pipette. A white pellet should be visible at the base of the microfuge tube.

27. Add $500 \mu \mathrm{L}$ of cold $70 \%$ ethanol to the microfuge tube to wash the pellet. Centrifuge the tube at $16,000 \mathrm{rpm}(25,200 \times g)$ for 5 min at $4{ }^{\circ} \mathrm{C}$ and remove the supernatant with an elongated Pasteur pipette.

28. Dry the pellet in a $37^{\circ} \mathrm{C}$ incubator for $15 \mathrm{~min}$ or on a benchtop for $1 \mathrm{~h}$. Dissolve the pellet in $17.0 \mu \mathrm{L}$ of $10 \mathrm{mM}$ Tris. Use $2.0 \mu \mathrm{L}$ of the library to determine DNA concentration using the Qubit ${ }^{\circledR}$ dsDNA HS Assay Kit. Ensure that at least $250 \mathrm{ng}$ of the Hi-C library is available for NGS Library preparation.

3.3 NGS Library Preparation
1. Remove glycogen and excess salt from the Hi-C library by mixing $45.0 \mu \mathrm{L}$ of Agencourt AMPure XP beads with 15.0 $\mu \mathrm{L}$ of the library in a PCR tube. Incubate the sample at room temperature for $5 \mathrm{~min}$ and follow the wash steps 
according to the manufacturer's instructions. Elute the DNA in $37.0 \mu \mathrm{L}$ of elution buffer (see Note 7 ).

2. Use $2.0 \mu \mathrm{L}$ of the library to determine DNA concentration using the Qubit ${ }^{\circledR}$ dsDNA HS Assay Kit. Proceed with library preparation if more than $200 \mathrm{ng}$ of the Hi-C library is available.

3. Add $5.0 \mu \mathrm{L}$ of $10 \times$ KAPA Frag buffer and $10.0 \mu \mathrm{L}$ of the KAPA Frag enzyme to the Hi-C library on ice.

4. Transfer the reaction to a thermocycler at $4{ }^{\circ} \mathrm{C}$ and run the following program:

\begin{tabular}{lll}
\hline Step & Temperature & Time \\
\hline Pre-cooled block & $4{ }^{\circ} \mathrm{C}$ & N/A \\
\hline Fragmentation & $37^{\circ} \mathrm{C}$ & $10 \mathrm{~min}$ \\
\hline Hold & $4{ }^{\circ} \mathrm{C}$ & $\infty$ \\
\hline
\end{tabular}

Maintain the temperature of the heated lid at $45{ }^{\circ} \mathrm{C}$ during fragmentation ( see Note $\mathbf{8}$ ).

5. Mix 7.0 $\mu \mathrm{L}$ of the End Repair and A-Tailing Buffer and 3.0 $\mu \mathrm{L}$ of the End Repair and A-Tailing Enzyme Mix on ice (supplied with the KAPA HyperPlus kit).

6. Immediately transfer the mix $(10.0 \mu \mathrm{L})$ to the fragmentation reaction at $4{ }^{\circ} \mathrm{C}$ and run the program below on a thermocycler:

\begin{tabular}{lll}
\hline Step & Temperature & Time \\
\hline Pre-cooled block & $4{ }^{\circ} \mathrm{C}$ & N/A \\
\hline End repair and A-tailing & $65^{\circ} \mathrm{C}$ & $30 \mathrm{~min}$ \\
\hline Hold & $20^{\circ} \mathrm{C}$ & $\infty$ \\
\hline
\end{tabular}

Maintain the temperature of the heated lid at $85^{\circ} \mathrm{C}$ during end repair and A-tailing ( see Note 8 ).

7. Immediately add the following to $60.0 \mu \mathrm{L}$ of end repaired and A-tailed DNA: $5.0 \mu \mathrm{L}$ of $15 \mu \mathrm{M}$ Illumina ${ }^{\circledR}$ paired-end sequencing adapter (barcoded), $5.0 \mu \mathrm{L}$ of elution buffer $+0.1 \%$ Tween $20,30.0 \mu \mathrm{L}$ of ligation buffer (KAPA HyperPlus), and $10.0 \mu \mathrm{L}$ of DNA Ligase (KAPA HyperPlus). To sequence several Hi-C libraries in a single Illumina ${ }^{\circledR}$ lane, ligate each library to a different sequencing adapter.

8 . Incubate the reaction at $20^{\circ} \mathrm{C}$ for $2 \mathrm{~h}$.

9. Transfer $50.0 \mu \mathrm{L}$ of Dynabeads ${ }^{\circledR}$ MyOne $^{\text {TM }}$ Streptavidin Tl into a PCR tube. Place the tube on a magnetic rack until the solution clears and carefully remove the supernatant with a pipette. 
10. Resuspend the beads in $50.0 \mu \mathrm{L}$ of $1 \times$ BWB by vortexing. Place the beads back on the magnetic rack until the solution clears and remove the supernatant. Perform this step twice.

11. Resuspend the beads in $50.0 \mu \mathrm{L}$ of $2 \times$ BWB by vortexing.

12. Clean up the ligation reaction (see step 8) with $110.0 \mu \mathrm{L}$ of Agencourt AMPure XP beads and elute the adapter-ligated Hi-C library in $50.0 \mu \mathrm{L}$ of elution buffer.

13. Mix the library with $50.0 \mu \mathrm{L}$ of Dynabeads ${ }^{\circledR}$ MyOne $^{\text {TM }}$ Streptavidin $\mathrm{Tl}$ in $2 \times \mathrm{BWB}$ ( see step 11). Incubate the sample for $45 \mathrm{~min}$ at $37^{\circ} \mathrm{C}$ in a ThermoMixer at $500 \mathrm{rpm}$.

14. Place the sample on a magnetic rack to collect the beads and carefully discard the supernatant.

15. Resuspend the beads in $50.0 \mu \mathrm{L}$ of elution buffer $+0.1 \%$ Tween 20 by vortexing. Collect the beads with the magnetic rack and discard the supernatant. Repeat this step twice.

16. Resuspend the beads in $20.0 \mu \mathrm{L}$ of elution buffer $+0.1 \%$ Tween 20.

17. To the adapter-ligated Hi-C library on beads (step 16), add: $25.0 \mu \mathrm{L}$ of $2 \times$ KAPA HiFi HotStart ReadyMix, and $5.0 \mu \mathrm{L}$ of $10 \times$ Library Amplification Primer Mix as supplied with the KAPA HyperPlus kit. Run the following program in a thermocycler to amplify the library:

\begin{tabular}{llll}
\hline Step & Temperature & Time & Cycles \\
\hline Initial denaturation & $98{ }^{\circ} \mathrm{C}$ & $45 \mathrm{~s}$ & $\mathrm{l}$ \\
Denaturation & $98{ }^{\circ} \mathrm{C}$ & $15 \mathrm{~s}$ & $6-8$ (see Note 9) \\
Annealing & $60^{\circ} \mathrm{C}$ & $30 \mathrm{~s}$ & \\
Extension & $72{ }^{\circ} \mathrm{C}$ & $30 \mathrm{~s}$ & \\
Final extension & $72{ }^{\circ} \mathrm{C}$ & $1 \mathrm{~min}$ & 1 \\
\hline Hold & $4{ }^{\circ} \mathrm{C}$ & $\infty$ & 1 \\
\hline
\end{tabular}

18. Collect the beads with the magnetic rack and transfer the supernatant (referred to hereafter as the sequencing library) into a new PCR tube. Place the tube on ice until needed. Proceed with processing the sequencing library at step 21.

19. Resuspend the beads in $50.0 \mu \mathrm{L}$ of elution buffer $+0.1 \%$ Tween 20 by vortexing and collect the beads using the magnetic rack. Remove the supernatant by pipetting. Repeat this step twice.

20. Resuspend the beads in $20.0 \mu \mathrm{L}$ of elution buffer $+0.1 \%$ Tween 20 and store the sample at $4{ }^{\circ} \mathrm{C}$. This adapter-ligated $\mathrm{Hi}$-C library on beads can be reused on a later date to prepare the sequencing library as outlined in steps 17 to 24 of this section. 
21. Purify the sequencing library (see step 18) with $35.0 \mu \mathrm{L}$ of Agencourt AMPure XP beads (see Note 7).

22. Elute the sequencing library in $11.0 \mu \mathrm{L}$ of elution buffer.

23. Use $1.0 \mu \mathrm{L}$ of the sequencing library to determine DNA concentration using the Qubit ${ }^{\circledR}$ dsDNA HS Assay Kit. Use the elution buffer to adjust library concentration to $5.0 \mathrm{ng} / \mu \mathrm{L}$.

24. Measure the concentration of the sequencing library to ensure that the dilution was performed accurately.

25. Multiple libraries, each marked with distinct Illumina ${ }^{\circledR}$ pairedend sequencing adapters, can now be pooled for sequencing. The ratio at which the libraries are pooled determines the fraction of total reads available for each library.

26. Assess the quality of the sequencing library by determining the size distribution of the DNA fragments using a Tapestation (Agilent Technologies) or Bioanalyzer (Agilent Technologies). If small amounts of adapters or adapter dimers remain, perform a second $0.7 \times$ SPRI bead purification.

\subsection{Data Analysis and Contact Maps Generation}

After deep sequencing, reads are mapped using an iterative method, then assigned to each restriction fragment. Self-circularized, unligated fragments and PCR artifacts are discarded using filtering and valid junctions are assigned to bins by their midpoint coordinate to generate a first raw contact map. If the binning process can reduce the resolution of the map, it also increases signal-to-noise ratio. The final normalized contact map is obtained after matrix balancing based on the nonuniform distribution of the length of restriction fragments and the nucleotide composition of the genome. In our experience, 15 million valid junction reads are enough to produce a normalized $5 \mathrm{~kb}$ resolution map. Chapter 2 provides a more detailed description of the analysis workflow for processing raw data into contact maps. Several software packages and online tools are also available to support researchers in analyzing $\mathrm{Hi}-\mathrm{C}$ data (see Note 10).

\section{Notes}

1. Buffers used for cell fixation should lack compounds that contain nucleophilic groups such as thiols, amines, and amides. The carbonyl moiety of formaldehyde reacts with these groups reducing the efficiency of cell fixation. It is therefore also necessary to wash the bacterial cells with $1 \times$ PBS prior to fixation (see step 2; Subheading 3.1) to remove components of the growth medium that react with formaldehyde. 
2. Restriction enzymes define the resolution of the Hi-C library. The enzyme is selected based on the criterion that it produces a non-degenerate $5^{\prime}$ overhang upon cleavage of its restriction site. This is necessary as $3^{\prime}$ overhangs cannot be filled in, and degenerate sticky ends may interfere with biotin tagging. It is necessary that the enzyme functions optimally at $37^{\circ} \mathrm{C}$ (or at an even lower temperature; for instance, the optimal temperature for CviAII activity is $25{ }^{\circ} \mathrm{C}$ ) as restriction digestion at higher temperatures leads to premature reverse cross-linking of DNA-protein complexes. To ensure a good digestion efficiency during library preparation, it is important that the activity of the selected enzyme is not blocked by DNA methylation. The size distribution of the predicted restriction fragments generated by the enzyme should also be evaluated to ensure that the enzyme generates limited, if any, restriction fragments with sizes greater than the chosen $\mathrm{Hi}-\mathrm{C}$ map resolution; long restriction fragments introduce biases in the contact matrix.

3. During the preparation of $\mathrm{Hi}-\mathrm{C}$ libraries, restriction fragment overhangs are filled in with biotin-labeled nucleotides to tag ligation junctions generated during the subsequent proximity ligation step. Ensure that the fill-in of the $5^{\prime}$ overhang generated by restriction digestion allows the incorporation of the selected biotin-labelled nucleotide. For instance, do not use biotin-14-dATP to fill-in overhangs generated by HpaII ( $\left.\mathrm{C}^{\wedge} \mathrm{CGG}\right)$.

4. Cells can be harvested for fixation at any stage of growth. However, it is necessary to maintain cell concentration during fixation. For this, adjust the volume of the harvested culture when fixation is performed on E. coli cells at a different $\mathrm{OD}_{600}$

5. Each $1 \mathrm{~mL}$ aliquot contains approximately $10^{9}$ fixed cells. This corresponds to $\sim 10 \mu \mathrm{g}$ of DNA.

6. Some chromatin fragments may have been filled in with biotinlabeled nucleotides, but may not have undergone ligation to give a chimeric product. Unligated "dangling ends" that are bound by streptavidin-coated magnetic beads and thereafter sequenced reduce the number of useful reads per sequencing run. Biotin removal from such ends is performed with T4 DNA Polymerase under conditions that favor the $3^{\prime}$ exonuclease activity of the enzyme in removing nucleotides past blunted ends. This condition is provided by maintaining the concentration of selected free nucleotides in the reaction mix below $100 \mu \mathrm{M}[7,8]$. For instance, for the removal of biotin-14dATP from the dangling ends of PsuI- or BglII-digested Hi-C libraries (RGA*TC), $100 \mu \mathrm{M}$ of dGTP is added to the reaction mix, whereas dATP, dCTP, and dTTP are not (see step 23 of Subheading 3.2). This way, nucleotides up to but 
excluding $\mathrm{G}$ will be removed as a result of the activation of the $5^{\prime}$ polymerase function of the enzyme at that site. The $3^{\prime}$ exonuclease activity of T4 DNA Polymerase is also favored by increasing enzyme concentration, extending reaction times, and incubation at higher temperatures, for instance, $16^{\circ} \mathrm{C}-$ as opposed to $12{ }^{\circ} \mathrm{C}$-to favor the breathing of DNA ends.

7. Solid Phase Reverse Immobilization (SPRI) beads reversibly bind DNA fragments in solution in the presence of Polyethylene glycol (PEG). The immobilization is size selective and depends on the concentration of PEG in the DNA-bead solution. Since PEG is present in the SPRI beads storage buffer (as supplied by the manufacturer), the size selective immobilization of DNA onto the SPRI beads is determined by the volumetric ratio rather than the concentration ratio of beads to DNA. Larger DNA fragments bind to the beads at low PEG concentrations. Thus, a $0.7 \times$ volumetric ratio of beads to DNA solution is used to remove the short-length adapters and adapter dimers from the sequencing library during NGS library preparation (see step 21; Subheading 3.3). Shorter DNA fragments can only be immobilized at higher PEG concentrations. Therefore, to remove glycogen and excess salts from the HiC library for NGS library preparation, a $3.0 \times$ volumetric ratio of beads to DNA solution is used (see step 1; Subheading 3.3).

8. Using a heated lid at a temperature $>50{ }^{\circ} \mathrm{C}$ during library fragmentation ( see step 4; Subheading 3.3) or $>85^{\circ} \mathrm{C}$ during end repair and A-tailing (see step 6; Subheading 3.3) overheats the reactions. This may result in a partial denaturation of the enzymes and a lower efficiency of the reactions.

9. These are the recommended number of cycles for 500-200 ng of input DNA as measured in step 2 of Subheading 3.3.

10. Software packages and online tools available to analyze and display $\mathrm{Hi}-\mathrm{C}$ interaction data:

- Juicer: https://github.com/theaidenlab/juicer

- HiCUP: http://www.bioinformatics.babraham.ac.uk/pro jects/hicup/

- Hi-C inspector: https://github.com/HiC-inspector/HiCinspector

- Hi-C pro: https://github.com/nservant/HiC-Pro

- HiTC: http://www.bioconductor.org/packages//2.10/ bioc/html/HiTC.html 
Acknowledgments

This work was supported by grants from the Netherlands Organization for Scientific Research [VICI 016.160.613] and the Human Frontier Science Program (HFSP) [RGP0014/2014].

\section{References}

1. Denker A, de Laat W (2016) The second decade of 3C technologies: detailed insights into nuclear organization. Genes Dev 30 (12):1357-1382. https://doi.org/10.1101/ gad.281964.116

2. Dixon JR, Selvaraj S, Yue F, Kim A, Li Y, Shen Y, Hu M, Liu JS, Ren B (2012) Topological domains in mammalian genomes identified by analysis of chromatin interactions. Nature 485 (7398):376-380. https://doi.org/10.1038/ nature 11082

3. Rao SSP, Huntley MH, Durand NC, Stamenova EK, Bochkov ID, Robinson JT, Sanborn AL, Machol I, Omer AD, Lander ES, Aiden EL (2014) A 3D map of the human genome at kilobase resolution reveals principles of chromatin looping. Cell 159(7):1665-1680. https:// doi.org/10.1016/j.cell.2014.11.021

4. Lieberman-Aiden E, Lieberman-Aiden E, van Berkum NL, van Berkum NL, Williams L, Williams L, Imakaev $M$, Imakaev $M$, Ragoczy T, Ragoczy T, Telling A, Telling A, Amit I, Amit I, Lajoie BR, Lajoie BR, Sabo PJ, Sabo PJ, Dorschner MO, Dorschner MO, Sandstrom R, Sandstrom R, Bernstein B, Bernstein B, Bender MA, Groudine $M$, Groudine M, Gnirke A, Gnirke A, Stamatoyannopoulos J, Stamatoyannopoulos J, Mirny LA, Mirny LA, Lander ES, Lander ES,
Dekker J, Dekker J (2009) Comprehensive mapping of long-range interactions reveals folding principles of the human genome. Science 326(5950):289-293. https://doi.org/10. 1126/science.1181369

5. Dame RT, Tark-Dame M (2016) Bacterial chromatin: converging views at different scales. Curr Opin Cell Biol 40:60-65. https://doi.org/10. 1016/j.ceb.2016.02.015

6. Le TBK, Imakaev MV, Mirny LA, Laub MT (2013) High-resolution mapping of the spatial organization of a bacterial chromosome. Science 342(6159):731-734. https://doi.org/10. $1126 /$ science. 1242059

7. Marbouty M, Le Gall A, Cattoni DI, Cournac A, Koh A, Fiche J-B, Mozziconacci J, Murray H, Koszul R, Nollmann M (2015) Condensin- and replication-mediated bacterial chromosome folding and origin condensation revealed by hi-C and super-resolution imaging. Mol Cell 59(4):588-602. https://doi.org/10.1016/j. molcel.2015.07.020

8. van Berkum NL, Lieberman-Aiden E, Williams L, Imakaev M, Gnirke A, Mirny LA, Dekker J, Lander ES (2010) Hi-C: a method to study the three-dimensional architecture of genomes. J Vis Exp (39). https://doi.org/l0. $3791 / 1869$ 